\title{
Pain Control: Normalization of the BPCQ Questionnaire on a Group of Patients Diagnosed with Malignant Cancer
}

\author{
Aleksandra Czerw ${ }^{1,2, *(\mathbb{D})}$, Urszula Religioni ${ }^{3}{ }^{\mathbb{D}}$, Filip Szymański ${ }^{4}$, Katarzyna Sygit ${ }^{5}$ (D), Krzysztof Zdziarski ${ }^{6}$, \\ Dominika Mękal ${ }^{7}$, Grażyna Dykowska ${ }^{1}$, Anna Kłak ${ }^{8} \mathbb{D}$, Agnieszka Barańska 9 ${ }^{\mathbb{D}}$, Piotr Merks ${ }^{10}$ (D), \\ Mariola Borowska ${ }^{1}$ (D) Elżbieta Cipora ${ }^{11}$ and Monika Pajewska $^{2}$ (D)
}

Citation: Czerw, A.; Religioni, U.; Szymański, F.; Sygit, K.; Zdziarski, K.; Mękal, D.; Dykowska, G.; Kłak, A.; Barańska, A.; Merks, P.; et al. Pain Control: Normalization of the BPCQ Questionnaire on a Group of Patients Diagnosed with Malignant Cancer. Int. J. Environ. Res. Public Health 2021, 18, 13069. https://doi.org/ 10.3390/ijerph182413069

Academic Editor: Miriam Sánchez-SanSegundo

Received: 14 October 2021

Accepted: 7 December 2021

Published: 11 December 2021

Publisher's Note: MDPI stays neutral with regard to jurisdictional claims in published maps and institutional affiliations.

Copyright: (c) 2021 by the authors Licensee MDPI, Basel, Switzerland. This article is an open access article distributed under the terms and conditions of the Creative Commons Attribution (CC BY) license (https:// creativecommons.org/licenses/by/ $4.0 /)$
1 Department of Health Economics and Medical Law, Medical University of Warsaw, 02-091 Warsaw, Poland; grazyna.dykowska@wum.edu.pl (G.D.); mariola.borowska@wum.edu.pl (M.B.)

2 Department of Economic and System Analyses, National Institute of Public Health NIH-National Research Institute, 00-791 Warsaw, Poland; mpajewska@pzh.gov.pl

3 Collegium of Business Administration, Warsaw School of Economics, 02-513 Warsaw, Poland; urszula.religioni@gmail.com

4 Department of Civilization Diseases, Faculty of Medicine, Collegium Medicum, Cardinal Stefan Wyszynski University in Warsaw, 01-938 Warsaw, Poland; f.szymanski@uksw.edu.pl

5 Faculty of Health Sciences, Calisia University, 62-800 Kalisz, Poland; ksygit@poczta.onet.pl

6 Department of Social Medicine and Public Health, Pomeranian Medical University in Szczecin, 70-204 Szczecin, Poland; krzysztof.zdziarski@pum.edu.pl

7 Department of Oncological Prevention, Medical University of Warsaw, 02-091 Warsaw, Poland; dmekal@wum.edu.pl

8 Department of Environmental Hazards Prevention, Allergology and Immunology, Medical University of Warsaw, 02-091 Warsaw, Poland; klak.anna2@gmail.com

9 Department of Computer Science and Medical Statistics, Medical University of Lublin, 20-090 Lublin, Poland; agnieszkabaranska@umlub.pl

10 Faculty of Medicine, Collegium Medicum, Cardinal Stefan Wyszynski University in Warsaw, 01-938 Warsaw, Poland; piotrmerks@googlemail.com

11 Faculty of Medical Science, Jan Grodek State University in Sanok, 38-500 Sanok, Poland; elacipora@interia.pl

* Correspondence: aleksandra.czerw@wum.edu.pl

Abstract: The purpose of this article is to examine the applicability of the Beliefs about Pain Control Questionnaire (BPCQ) among cancer patients and develop norms that allow differentiation of patients with diagnosed cancer in terms of beliefs about pain control. Normalization aims to establish the value of test results in the study population. The study involved 1187 patients diagnosed with cancer in outpatient care Maria Sklodowska-Curie Cancer Center and Institute of Oncology, in Warsaw. The applied tool was the Beliefs about Pain Control Questionnaire developed by S. Skevington. The results are most strongly differentiated in each dimension of pain control by education, income, and professional status. Sten norms were developed to determine the level of beliefs about pain control in low, average, and high categories. The BPCQ assessment applies to cancer patients, and the assessment of the location of pain control in patients will allow for the identification of patients whose standard therapy should be supplemented with psychotherapeutic support.

Keywords: pain; pain control; BPCQ assessment; normalization; cancer

\section{Introduction}

Cancer is the second cause of death in Poland, and forecasts indicate that in the next decade, cancer will be the leading cause of death [1,2]. Additionally, 18.1 million new incidents of cancer and 9.6 million deaths were registered worldwide in 2018 [3].

Cancer is associated with various ailments, the most common of which is pain. According to the definition of the International Association for the Study of Pain (IASP), pain is an unpleasant sensory and emotional experience associated with current or potential tissue damage or described in terms of such damage. 
Studies show that 30-50\% of people experience pain during active cancer therapy, and even up to $90 \%$ of patients in the later stages of the disease. Moderate-to-severe pain occurs in approximately $40 \%$ of patients in moderate stages of the disease, and pain attacks in approximately $80 \%$ of patients in advanced stages of cancer [4].

Pain has its cognitive, emotional, and behavioral consequences. Pain is a subjective and multidimensional experience, which is why there are significant difficulties in its direct and objective assessment [5]. The pain response is not innate and automatic. It is a result of the patient's beliefs and reaction to pain and, as studies show, it can be significantly modified by the social environment [4]. Psychological factors play a crucial role in reaction to pain [6]. There are studies that explored the relationship between hope and pain among oncology patients; however, it is important to take into account biological, psychological, and social contexts as well $[7,8]$.

Among other factors, the localization of sense of control is also a variable associated with pain [9]. The sense of control is an individual human property that can be treated as a personality trait that can be represented on a continuum from a sense of external control to a sense of internal control. Persons with an internal location of control (inner directed) recognize that they exercise control, are responsible, and treat encountered situations as the result of their own actions. Persons with an external location of control (other directed) feel less personal responsibility and more often grant it to external factors, i.e., happiness, chance, or actions of others [5].

Studies indicate the relationship between the location of health control and undertaking health behaviors $[9,10]$. The internal location of control, i.e., convincing the patient about his/her own impact on the course of the illness, increases the sense of agency and thus promotes undertaking pro-health behaviors and taking responsibility for their own health [11], although it is indicated that people with an internal location of health control are more responsible for their health, but only when they treat it as a value [12].

Beliefs and the attitude of patients toward pain affect the severity of pain, as well as the feeling of other symptoms associated with the illness, compliance with medical recommendations, and the final results of treatment [13-15]. Studies also emphasize the impact of the internal pain control factor on patient optimism and the perception of positives in their illness [16]. In turn, the external location of control affects the search for medical information, but it is not associated with the desire to independently solve health problems and the tendency to accept the possibility of active participation in treatment [10].

Beliefs about pain control are measured using the Beliefs about Pain Control Questionnaire (BPCQ), developed by S. Skevington [11]. The questionnaire is used in the examination of adults complaining of pain, both at the stage of diagnosis and therapy. It measures the strength of individual beliefs about controlling pain personally (internal factors), through the influence of physicians (the strength of others), and through random events.

The main objective of the study is the normalization of the Beliefs about Pain Control Questionnaire (BPCQ) for cancer patients. Normalization allows norms regarding test results to be established for a specific population. This procedure allows for an understanding of what the result obtained by a specific person in the questionnaire means, including whether the result is high or low.

\section{Materials and Methods}

\subsection{Characteristics of the Studied Normalization Group}

The normalization sample included results of 1187 respondents aged 21-96 $(\mathrm{M}=62.12$; $\mathrm{SD}=14.03), 666$ women aged $21-96(\mathrm{M}=58.17 ; \mathrm{SD}=12.88)$ and 521 men aged 22-96 $(\mathrm{M}=67.12 ; \mathrm{SD}=13.75)$. The criteria for enrolling patients were the patient's availability at the Maria Sklodowska-Curie Cancer Center and Institute of Oncology, in Warsaw, for the duration of the study and the patient's consent to participate in the study. 
The structure of diagnoses among the studied women was as follows: breast cancer, $29 \%$; ovarian cancer, $25.8 \%$; endometrial cancer, $17.4 \%$; colorectal cancer, $14.9 \%$; stomach cancer, $6.8 \%$; pancreatic cancer, $3.6 \%$; bladder cancer, $2.6 \%$. In the studied group of men, the following types of cancer occurred: prostate cancer, $43.8 \%$; colorectal cancer, $26.9 \%$; bladder cancer, $15.9 \%$; stomach cancer, $9.2 \%$; pancreatic cancer, $4.2 \%$ (Table 1 ).

Table 1. Types of cancer in the studied group and in the population.

\begin{tabular}{|c|c|c|c|c|c|c|}
\hline \multirow[b]{2}{*}{ Cancer Location } & \multicolumn{3}{|c|}{ Women } & \multicolumn{3}{|c|}{ Men } \\
\hline & Population (\%) & Sample (\%) & Weight & Population (\%) & Sample (\%) & Weight \\
\hline Breast cancer & 21.9 & 29.0 & 0.76 & 0 & 0 & - \\
\hline Ovarian cancer & 4.7 & 25.8 & 0.18 & 0 & 0 & - \\
\hline Stomach cancer & 2.4 & 6.8 & 0.35 & 4.5 & 9.2 & 0.49 \\
\hline Colorectal cancer & 10.1 & 14.9 & 0.68 & 12.2 & 26.9 & 0.45 \\
\hline Prostate cancer & 0 & 0 & - & 15.5 & 43.8 & 0.35 \\
\hline Bladder cancer & 2.0 & 2.6 & 0.77 & 6.9 & 15.9 & 0.43 \\
\hline Endometrial cancer & 7.3 & 17.4 & 0.42 & 0 & 0 & - \\
\hline Pancreatic cancer & 2.2 & 3.6 & 0.61 & 2.3 & 4.2 & 0.55 \\
\hline
\end{tabular}

In the studied group, the majority of patients had secondary education $(37.7 \%)$ or higher education (33.1\%). The largest group of people lived in cities over 500,000 inhabitants $(36.0 \%)$, and the average monthly income per person in a household was over 2000 PLN for $27.7 \%$ of people, $1001-1500$ PLN for $26.7 \%$ of people, and 1501-2000 PLN for $25.2 \%$ of people. The majority of patients were pensioners $(52.1 \%)$, but a large number of participants were also professionally active (39.1\%). Patients were mainly married (68.4\%). Detailed information about the sample is presented in Table 2.

Table 2. Characteristics of the studied normalization sample.

\begin{tabular}{|c|c|c|}
\hline Characteristic & $n$ & $\%$ \\
\hline \multicolumn{3}{|l|}{ Education } \\
\hline Primary & 97 & 8.3 \\
\hline Vocational & 250 & 21.1 \\
\hline Secondary & 447 & 37.7 \\
\hline Higher & 393 & 33.1 \\
\hline \multicolumn{3}{|l|}{ Place of residence } \\
\hline Village & 221 & 18.6 \\
\hline City up to 20,000 inhabitants & 131 & 11.0 \\
\hline City up to 50,000 inhabitants & 154 & 13.0 \\
\hline City up to 100,000 inhabitants & 144 & 12.1 \\
\hline City up to 500,000 inhabitants & 110 & 9.3 \\
\hline City above 500,000 inhabitants & 427 & 36.0 \\
\hline \multicolumn{3}{|l|}{ Average monthly income } \\
\hline No data & 8 & 0.7 \\
\hline Below 500 PLN & 24 & 2.0 \\
\hline 501-1000 PLN & 210 & 17.7 \\
\hline 1001-1500 PLN & 317 & 26.7 \\
\hline 1501-2000 PLN & 299 & 25.2 \\
\hline Above 2000 PLN & 329 & 27.7 \\
\hline \multicolumn{3}{|l|}{ Professional status } \\
\hline Working & 464 & 39.1 \\
\hline Student & 19 & 1.6 \\
\hline Retired/pensioner & 618 & 52.1 \\
\hline Homemaker & 53 & 4.5 \\
\hline Unemployed & 33 & 2.8 \\
\hline \multicolumn{3}{|l|}{ Marital status } \\
\hline Unmarried & 93 & 7.8 \\
\hline Married & 812 & 68.4 \\
\hline Widow/widower & 192 & 16.2 \\
\hline Divorced & 90 & 7.6 \\
\hline Total & 1187 & 100 \\
\hline
\end{tabular}




\subsection{Tool Applied}

The BPCQ assessment, measuring the strength of individual beliefs about pain control, consists of 13 statements that make up three factors of pain control:

Internal factors (a belief in pain control personally);

Influence of physicians (a belief that pain is controlled by others);

Random events (a belief that there is no self-influence on pain control).

The questionnaires used in the study are the only version of the BPCQ test available in Poland through the Psychological Testing Laboratory of the Polish Society of Psychology (translation by Juczyński) [17]. The statements in the questionnaire should be assessed by the patient at a six-point Likert scale, where 1 means "no, I completely do not agree" and 6 indicates "yes, I totally agree". The results of the questionnaire are not given in the form of one indicator, but for each dimension of the location of control, the sum of the results is calculated separately. The range of points possible to obtain is from 5 to 30, in the area of external control, and from 4 to 24 in the areas of influence of physicians and random events. The higher the score of a given area, the stronger the belief that pain can be controlled by the patient through the strength of a given factor.

The Cronbach's alpha internal compatibility index, according to Juczyński, was 0.75 for the whole scale and 0.86 for the influence of physicians, 0.82 for the area related to internal factors, and a low value of 0.58 for the impact of random events [17]. In the current sample, Cronbach's alpha coefficients were equal to 0.81 for the whole scale and 0.78 for the influence of physicians, 0.82 for the area related to internal factors, and 0.66 for the impact of random events.

Statistical analysis was performed with the use of IBM SPSS 25.0 software. The analysis regarding between groups comparisons was based on the values of an independent $t$-test when comparing two groups (gender, city/town size, working people vs. retirees/pensioners) and on the values of one-way analysis of variance when analyzing education. The analysis of variance was followed by Gabriel's post hoc test which was designed for analyzing unequal groups [18]. The groups of participants with primary and vocational education were combined in order to avoid analyzing very small groups (participants with primary education). Students, homemakers, and unemployed patients were excluded from the analysis concerning professional status due to the small number of participants in these three groups. Correlations were analyzed with the use of Pearson's correlation coefficient.

\section{Results}

Tables $3-5$ present descriptive statistics for the intensification of the internal location of pain control (Table 3), the location of pain control in the influence of physicians (Table 4), and the location of pain control in random events (Table 5) depending on demographic variables along with the values of tests concerning the significance of statistical differences.

Table 3. Descriptive statistics for the intensification of the internal location of control depending on demographic variables.

\begin{tabular}{|c|c|c|c|c|c|c|c|}
\hline & & $\mathbf{M}$ & SD & Min & Max & Test & $p$ \\
\hline \multirow[t]{2}{*}{ Gender } & Women & 16.11 & 5.39 & 5 & 30 & $t(550)=-0.82$ & 0.410 \\
\hline & Men & 16.51 & 5.68 & 5 & 30 & & \\
\hline \multirow[t]{3}{*}{ Education } & Prim./voc. & 17.08 & 5.73 & 5 & 30 & $F(2.549)=3.15$ & 0.044 \\
\hline & Secondary & 16.25 & 5.55 & 5 & 30 & & \\
\hline & Higher & 15.58 & 5.16 & 5 & 30 & & \\
\hline \multirow{2}{*}{$\begin{array}{l}\text { City/town } \\
\text { size }\end{array}$} & Up to 100.000 inhabitants & 16.27 & 5.52 & 5 & 30 & $t(550)=0.04$ & 0.972 \\
\hline & Above 100.000 inhabitants & 16.26 & 5.49 & 5 & 30 & & \\
\hline \multirow{2}{*}{$\begin{array}{c}\text { Net } \\
\text { income }\end{array}$} & Up to 1.500 PLN & 16.55 & 5.45 & 5 & 30 & $t(550)=1.18$ & 0.239 \\
\hline & Above 1.500 PLN & 16.00 & 5.54 & 5 & 30 & & \\
\hline \multirow{6}{*}{$\begin{array}{c}\text { Professional } \\
\text { status }\end{array}$} & Working & 16.12 & 5.09 & 5 & 30 & $t(502)=-0.67$ & 0.501 \\
\hline & Student & 17.57 & 7.25 & 8 & 30 & & \\
\hline & Retired/pensioner & 16.45 & 5.73 & 5 & 30 & & \\
\hline & Homemaker & 15.71 & 5.18 & 6 & 28 & & \\
\hline & Unemployed & 15.21 & 6.86 & 5 & 26 & & \\
\hline & Total & 16.27 & 5.50 & 5 & 30 & & \\
\hline
\end{tabular}

$\mathrm{M}$-median; SD—standard deviation; min—minimum value; max—maximum value; $t$-Student's $t$-test value for independent samples; F-one-way analysis of variance value; $p$ —statistical significance. 
Table 4. Descriptive statistics for the intensification of the location of pain control in the influence of physicians depending on demographic variables.

\begin{tabular}{|c|c|c|c|c|c|c|c|}
\hline & & $\mathbf{M}$ & SD & Min & Max & Test & $p$ \\
\hline \multirow{2}{*}{ Gender } & Women & 16.42 & 4.58 & 4 & 24 & $t(550)=-0.07$ & 0.943 \\
\hline & Men & 16.45 & 4.84 & 4 & 24 & & \\
\hline \multirow[t]{3}{*}{ Education } & Prim./voc. & 17.04 & 4.98 & 4 & 24 & $F(2.549)=5.52$ & 0.004 \\
\hline & Secondary & 16.77 & 4.37 & 4 & 24 & & \\
\hline & Higher & 15.50 & 4.65 & 4 & 24 & & \\
\hline \multirow{2}{*}{$\begin{array}{l}\text { City/town } \\
\text { size }\end{array}$} & Up to 100.000 inhabitants & 16.45 & 4.64 & 4 & 24 & $t(550)=0.07$ & 0.947 \\
\hline & Above 100.000 inhabitants & 16.42 & 4.73 & 4 & 24 & & \\
\hline \multirow{2}{*}{$\begin{array}{c}\text { Net } \\
\text { income }\end{array}$} & Up to 1.500 PLN & 16.90 & 4.67 & 4 & 24 & $t(550)=2.29$ & 0.023 \\
\hline & Above 1.500 PLN & 16.00 & 4.65 & 4 & 24 & & \\
\hline \multirow{6}{*}{$\begin{array}{l}\text { Professional } \\
\text { status }\end{array}$} & Working & 15.74 & 4.40 & 4 & 24 & $t(502)=-3.12$ & 0.002 \\
\hline & Student & 16.75 & 5.34 & 8 & 24 & & \\
\hline & Retired/pensioner & 17.03 & 4.73 & 4 & 24 & & \\
\hline & Homemaker & 15.41 & 5.66 & 5 & 24 & & \\
\hline & Unemployed & 16.68 & 4.29 & 9 & 24 & & \\
\hline & Total & 16.43 & 4.68 & 4 & 24 & & \\
\hline
\end{tabular}

$\mathrm{M}$-median; SD—standard deviation; min-minimum value; max-maximum value; $t$-Student's $t$-test value for independent samples; F-one-way analysis of variance value; $p$-statistical significance.

Table 5. Descriptive statistics for the intensification of the location of pain control in random events depending on demographic variables.

\begin{tabular}{|c|c|c|c|c|c|c|c|}
\hline & & $\mathbf{M}$ & SD & Min & $\operatorname{Max}$ & Test & $p$ \\
\hline \multirow[t]{2}{*}{ Gender } & Women & 15.47 & 4.48 & 4 & 24 & $t(550)=0.62$ & 0.534 \\
\hline & Men & 15.22 & 4.83 & 4 & 24 & & \\
\hline \multirow[t]{3}{*}{ Education } & Prim./voc. & 16.38 & 4.62 & 4 & 24 & $F(2.549)=11.12$ & 0.001 \\
\hline & Secondary & 15.66 & 4.36 & 4 & 24 & & \\
\hline & Higher & 14.12 & 4.68 & 4 & 24 & & \\
\hline \multirow{2}{*}{$\begin{array}{l}\text { City/town } \\
\text { size }\end{array}$} & Up to 100.000 inhabitants & 15.52 & 4.58 & 4 & 24 & $t(550)=0.85$ & 0.395 \\
\hline & Above 100.000 inhabitants & 15.18 & 4.68 & 4 & 24 & & \\
\hline \multirow{2}{*}{$\begin{array}{c}\text { Net } \\
\text { income }\end{array}$} & Up to 1.500 PLN & 16.09 & 4.47 & 4 & 24 & $t(550)=3.61$ & 0.001 \\
\hline & Above 1.500 PLN & 14.69 & 4.66 & 4 & 24 & & \\
\hline \multirow{6}{*}{$\begin{array}{c}\text { Professional } \\
\text { status }\end{array}$} & Working & 14.71 & 4.53 & 4 & 24 & $t(502)=-3.07$ & 0.002 \\
\hline & Student & 15.56 & 6.09 & 6 & 24 & & \\
\hline & Retired/pensioner & 15.97 & 4.60 & 4 & 24 & & \\
\hline & Homemaker & 15.00 & 4.32 & 5 & 23 & & \\
\hline & Unemployed & 13.89 & 5.06 & 4 & 24 & & \\
\hline & Total & 15.37 & 4.62 & 4 & 24 & & \\
\hline
\end{tabular}

$\mathrm{M}$-median; SD—standard deviation; min-minimum value; max-maximum value; $t$-Student's $t$-test value for independent samples; $\mathrm{F}$-one-way analysis of variance value; $p$-statistical significance.

Based on Gabriel's post hoc test, it was found that statistically significant differences in the internal location of pain control occurred between the group of people with primary or vocational education $(\mathrm{M}=16.38)$ and the group of people with higher education $(\mathrm{M}=14.12)(p<0.05)$. It was found that the intensity of the location of pain control in the influence of physicians was the lowest in the group of people with higher education $(\mathrm{M}=15.50)$, compared with the average of people with secondary education $(\mathrm{M}=16.77)$ and primary/vocational $(\mathrm{M}=17.04)$; it was lower in the group of people with a monthly net income per person in the family above 1500 PLN $(M=16.00)$, compared with people with an income of up to 1500 PLN $(M=16.90)$ and lower in the group of working people $(\mathrm{M}=15.74)$ than retirees/pensioners $(\mathrm{M}=17.03)$.

It was found that the intensity of the location of pain control in random events was the lowest in the group of people with higher education $(\mathrm{M}=14.12)$ in comparison with people with secondary education $(\mathrm{M}=15.66)$ and primary/vocational education $(\mathrm{M}=16.38)$. The location of pain control in random events was also lower in the group of people with a monthly net income per person in the family above 1500 PLN $(\mathrm{M}=14.69)$, compared 
with people with lower income $(\mathrm{M}=16.09)$, and lower in the group of employed people $(\mathrm{M}=14.71)$ than in the group of retired people/pensioners $(\mathrm{M}=15.97)$.

No statistically significant differences between the genders were found; therefore, the norms were determined for the whole sample studied together. Based on the value of the Pearson correlation coefficient $r$, no statistically significant correlation was found between the age of the respondents and the internal location of pain control, $\mathrm{r}(548)=0.08, p>0.05$. Correlation between the age of the respondents and the location of pain control for the group attributing control to the influence of physicians was statistically significant but weak. Identically, age and the location of pain control for the group attributing control to random events, was statistically significant and positive but weak. It was, respectively, $\mathrm{r}(548)=0.15, p<0.001$ for the location of pain control in the group attributing control to the influence of physicians and $\mathrm{r}(548)=0.17, p<0.001$ for the location of pain control in the group attributing control to random events.

Analysis of the results did not show statistically significant differences in the method of pain control depending on the type of patient treatment or metastases (in all cases $p<0.05$ ).

Norms

Tables 6-8 present values of sten and centile norms determined in the studied sample using the calculated weight for the results on the scale of internal control location (Table 6), the location of control in the group attributing control to the influence of physicians (Table 7), and those attributing control to random events (Table 8). Sten scores from 1 to 3 sten should be interpreted as low, from 4 to 7 sten as average, and from 8 to 10 sten as high

Table 6. Raw results and corresponding results normalized for the results on the scale internal location of control.

\begin{tabular}{|c|c|c|c|}
\hline Results & Value & Sten & Centile \\
\hline \multirow[t]{6}{*}{ Low } & 5 & 1 & 1 \\
\hline & 6 & 2 & 4 \\
\hline & 7 & 2 & 6 \\
\hline & 8 & 3 & 8 \\
\hline & 9 & 3 & 10 \\
\hline & 10 & 3 & 14 \\
\hline \multirow[t]{11}{*}{ Average } & 11 & 4 & 18 \\
\hline & 12 & 4 & 22 \\
\hline & 13 & 4 & 28 \\
\hline & 14 & 5 & 34 \\
\hline & 15 & 5 & 41 \\
\hline & 16 & 5 & 49 \\
\hline & 17 & 6 & 55 \\
\hline & 18 & 6 & 62 \\
\hline & 19 & 6 & 69 \\
\hline & 20 & 7 & 75 \\
\hline & 21 & 7 & 81 \\
\hline \multirow[t]{9}{*}{ High } & 22 & 8 & 85 \\
\hline & 23 & 8 & 88 \\
\hline & 24 & 8 & 91 \\
\hline & 25 & 9 & 94 \\
\hline & 26 & 9 & 96 \\
\hline & 27 & 9 & 98 \\
\hline & 28 & 10 & 99 \\
\hline & 29 & 10 & 99 \\
\hline & 30 & 10 & 100 \\
\hline
\end{tabular}


Table 7. Raw results and corresponding results normalized for the results on the scale of location of pain control in the group attributing control to the influence of physicians.

\begin{tabular}{cccc}
\hline Results & Value & Sten & Centile \\
\hline Low & 4 & 1 & 1 \\
& 5 & 1 & 2 \\
& 6 & 2 & 2 \\
& 7 & 2 & 3 \\
& 8 & 2 & 4 \\
& 9 & 2 & 6 \\
& 10 & 3 & 9 \\
Average & 11 & 3 & 13 \\
& 12 & 4 & 17 \\
& 13 & 4 & 22 \\
& 14 & 4 & 29 \\
& 15 & 5 & 37 \\
& 16 & 5 & 46 \\
& 17 & 6 & 55 \\
& 18 & 6 & 62 \\
& 19 & 6 & 68 \\
& 20 & 7 & 76 \\
& 21 & 7 & 82 \\
\hline High & 22 & 8 & 86 \\
& 23 & 8 & 90 \\
& 24 & 9 & 96 \\
\hline
\end{tabular}

Table 8. Raw results and corresponding results normalized for the results on the scale of location of pain control in the group attributing control to random events.

\begin{tabular}{cccc}
\hline Results & Value & Sten & Centile \\
\hline Low & 4 & 1 & 1 \\
& 5 & 2 & 2 \\
& 6 & 2 & 3 \\
& 7 & 2 & 5 \\
& 8 & 3 & 7 \\
& 9 & 3 & 10 \\
Average & 10 & 3 & 13 \\
& 11 & 4 & 17 \\
& 12 & 4 & 23 \\
& 13 & 4 & 29 \\
& 14 & 5 & 37 \\
& 15 & 5 & 45 \\
& 16 & 6 & 53 \\
& 17 & 6 & 62 \\
& 18 & 6 & 69 \\
& 19 & 7 & 77 \\
& 20 & 7 & 84 \\
\hline High & 21 & 8 & 89 \\
& 22 & 8 & 93 \\
& 23 & 9 & 96 \\
& 24 & 10 & 98 \\
\hline
\end{tabular}

\section{Discussion}

Each disease is associated with some discomfort and limitations, and many diseases are accompanied by pain [19]. Cancer is particularly associated with the experience of pain.

Numerous studies show that psychosocial factors, socio-cultural, cognitive, and emotional-motivational processes play a significant role in experiencing pain. Great importance is attributed to the location of pain control. In psychology, the sense of being 
under control indicates the patient's belief that he or she has an influence on a number of events in life, including achieving his/her goals [20,21].

Results of the authors' study show that individual dimensions of pain control are strongly conditioned by the level of education, professional status, and income of patients. A high inner sense of control is associated with better mental well-being, which is observed, among others, in chronically ill patients, which is emphasized by a number of authors, including Wallston and Thompson $[10,21]$. This information is a valuable source, especially for clinical psychologists, who can more easily identify the groups of people who should receive psychological support, especially in the area of increasing self-confidence in the fight against the disease.

People with an internal location of control are more prone to broadening their knowledge about health [22], active ways of coping, as well as health-related behaviors such as taking medications regularly, regular follow-ups, following a diet, or giving up smoking [12]. It is believed that this approach reduces hopelessness and depressive symptoms and promotes greater activity in an individual and helps them better cope with pain $[23,24]$.

In turn, people with a low sense of internal control more often negate symptoms of the disease and the need to comply with health-promoting behaviors. These people may trust others (influence of physicians) or believe that all events are random [10]. An external location of health control is generally associated with chronic negative emotions experienced by patients: depression, hostility, anxiety, as well as other more strongly felt symptoms associated with the disease. People with an external location of control use passive ways of coping with pain and illness and are less likely to choose positive forms of adaptation to the illness [10,19]. People with an external location of control usually do not care about expanding knowledge about their health [10,22,23].

Juczyński also indicates a link between the location of pain control and acceptance of the disease - patients who accept the disease less often attribute pain to the influence of physicians than patients who do not accept the disease [17].

The results of the authors' study indicate that patients diagnosed with chronic pain, migraine, multiple sclerosis, and malignant neoplasms obtained average results (close to the center of a scale used) in each area of pain control. Some studies prove that the external location of control is more common among women than men $[19,25]$, although such a relationship was not found in the authors' study, or the study conducted by Basińska et al. [12].

In the study conducted by Basinska et al., among patients with lung cancer, the dominant location of control concerned the area of influence of physicians $(\mathrm{M}=17.08$; $\mathrm{SD}=4.97)$, which was also observed among patients with colorectal cancer $(\mathrm{M}=16.98$; $\mathrm{SD}=4.32$ ). In both groups, patients attributed the least importance to the impact of random events [12]. In the authors' study, patients also obtained slightly higher results for the areas of the impact of physicians and internal factors than for the random events.

In the study of cancer patients, both treated causally as well as symptomatically, it was observed that patients treated symptomatically placed control in the area of the influence of physicians $(\mathrm{M}=20.23$; $\mathrm{SD}=3.44)$ and random events $(\mathrm{M}=17.90 ; \mathrm{SD}=3.93)$ in comparison with causally treated patients (respectively, $\mathrm{M}=17.80$ and $\mathrm{SD}=2.89$ for the impact of physicians; $\mathrm{M}=15.05$ and $\mathrm{SD}=3.08$ for random events). In the same study, it was demonstrated that patients at the terminal stage assigned much more importance to physicians and random events than to internal factors. It was also noted that people dominated by anxiety attributed a greater role to the influence of physicians or random events, while people showing a positive approach to the disease were more often characterized by an internal location of pain control [4].

BPCQ test results were varied among other groups of patients. Patients with chronic lower limb ischemia attributed the greatest importance in pain control to the influence of physicians $(M=19.04)$. Patients attributed less importance to random events. The average point value described the impact of random events $(M=16.85)$, and these beliefs were reflected by a significant share of lifestyle risk factors. Patients who were not convinced of their own influence on the control of ischemic pain did not take responsibility for their 
own health and well-being. They undertook behaviors unfavorable for the course of the disease, including smoking even though it increased the level of pain [26].

Additionally, among people with spine diseases, the external location of control dominated (mainly in the area of random events) [22]. In another study involving patients in chronic pain outpatient clinics (mainly cancer patients), it was found that the location of pain control in patients was affected by sociodemographic factors such as age, education, and professional status. Among persons under 40 years of age, patients controlled pain mainly through internal factors, but among older patients, the influence of physicians dominated. Patients' beliefs about self-control as a method of controlling pain increased with the degree of education. In turn, random events were of the least importance among people with higher education. For employed people and retirees, physicians constituted the most important factor in pain control $[27,28]$.

In patients with osteoarthritis of the spine, it was also noted that people with higher education less often pointed to the significant influence of physicians on the perception of pain. A significant relationship was also observed in relation to the gender of the respondents-men more often indicated the role of internal pain control [23].

Among patients after cardiac surgery, older patients $(\mathrm{M}=17.1 ; \mathrm{SD}=2.21)$, compared with younger patients $(\mathrm{M}=10.5 ; \mathrm{SD}=3.53)$, placed greater emphasis on the influence of physicians in controlling pain, and they also attributed a greater role to random events, which in older people was at the level of $\mathrm{M}=16.1$ ( $\mathrm{SD}=2.9$ ), while in younger people, $\mathrm{M}=12.0(\mathrm{SD}=2.82)[29,30]$.

In turn, a study involving patients with a history of chronic pain lasting over 12 weeks conducted at a pain clinic indicates that patients' behavior, related to the sensation of pain, as well as the results of treatment, is influenced by their knowledge about health (health literacy), including the ability to understand it and implement specific health-promoting behaviors [31]. This study indicates that patients during the treatment process need understandable knowledge about their clinical condition and justification of decisions made by medical staff regarding the selection of specific therapies, which can significantly affect faith in their own strength and an increase in the internal dimension of pain control. Changing attitudes and beliefs of patients regarding pain are considered to be an improvement in the treatment of chronic pain. Multidisciplinary approaches to pain, taking into account psychological aspects by changing the approach to one's illness and perceived pain, allow for the reduction in the perception of pain and improvement of treatment effectiveness [32].

\section{Limitations}

The authors' study has limitations; firstly, the influence of the stage of the disease or the type of treatment was not taken into account in the results obtained. Further research in this area may reveal additional links between pain control and other factors that affect the type of perception of pain control in a patient.

\section{Conclusions}

Studies on pain should take into account the biological, psychological, and social contexts. Pain is a psychosomatic symptom that requires both the use of appropriate medications and, above all, psychological support. The perception of pain by patients is not homogeneous, and therefore, patients with the same disease should not be treated equally in terms of their approach to pain relief.

The tool used in the assessment of pain control of cancer patients is the Beliefs about Pain Control Questionnaire. The assessment of the location of pain control translates into the level of pain experienced by patients, assessment of patients' coping resources, or the effectiveness of using these resources in the treatment process. This kind of approach to patients allows for the isolation of the group of patients who will require psychological support as a supplement to standard treatment. 
The conducted study allowed the norms (mean results) of the BPCQ assessment o be established for oncological patients. This information is especially valuable for psychologists working with patients. Knowledge of norms and sociodemographic variables that may affect the results allows health professionals to distinguish those groups of patients who have, for example, a low sense of self-control of health and thus should receive psychological support.

Author Contributions: A.C. and U.R. contributed to all aspects of the study's design, data analysis, interpretation, and writing the article; F.S. and K.S. contributed to the study's design and writing the article; K.Z., D.M., G.D., A.K., A.B., P.M., M.B., E.C. and M.P. contributed to data analysis and writing. All authors have read and agreed to the published version of the manuscript.

Funding: This research received no external funding.

Institutional Review Board Statement: Not applicable.

Informed Consent Statement: Informed consent was obtained from all subjects involved in the study. Due to the scope of the data, we obtained verbal informed consent.

Conflicts of Interest: The authors declare no conflict of interest.

\section{References}

1. Uchmanowicz, I.; Kołtunik, A.; Ryznar, M.; Rosińczuk, J. Quality of life assessment of patients under stationary palliative care. Pielegniarstwo i Zdr. Publiczne Nurs. Public Health 2015, 5, 5-9.

2. Nowak, A.; Babiarczyk, B.; Skoczylas, K. The effect of pain control and management strategies on psychological adaptation to cancer. J. Public Health Nurs. Med. Rescue 2018, 3, 6-12.

3. Bray, F.; Ferlay, J.; Soerjomataram, I.; Siegel, R.L.; Torre, L.A.; Jemal, A. Global cancer statistics 2018: GLOBOCAN estimates of incidence and mortality worldwide for 36 cancers in 185 countries. CA Cancer J. Clin. 2018, 68, 394-424. [CrossRef]

4. Krawczyk, A. Pain control in oncological patients treated causally and symptomatically. Psychoonkologia 2015, 1, 12-18.

5. Przybyłko, K.; Walesa, C.Z. Psychological problems of pain. Horyz. Psychol. 2016, 6, 105-127.

6. Linton, S.J.; Shaw, W.S. Impact of psychological factors in the experience of pain. Phys. Ther. 2011, 91, 700-711. [CrossRef]

7. Rawdin, B.; Evans, C.; Rabow, M.W. The relationships among hope, pain, psychological distress, and spiritual well-being in oncology outpatients. J. Palliat. Med. 2013, 16, 167-172. [CrossRef] [PubMed]

8. Syrjala, K.L.; Jensen, M.P.; Mendoza, M.E.; Yi, J.C.; Fisher, H.M.; Keefe, F.J. Psychological and behavioral approaches to cancer pain management. J. Clin. Oncol. 2014, 32, 1703-1711. [CrossRef] [PubMed]

9. Arraras, J.I.; Wright, S.J.; Jusue, G.; Tejedor, M.; Calvo, J.I. Coping style, locus of control, psychological distress and pain-related behaviours in cancer and other diseases. Psychol. Health Med. 2002, 7, 181-187. [CrossRef]

10. Wallston, K.A.; Wallston, B.S. Who is responsible for your health. The construct of health locus of control. In Social Psychology of Health and Illness; Sanders, G., Suls, J., Eds.; Lawrence Erl-baum \& Associates: Hillsdale, NJ, USA, 1982; pp. 65-95.

11. Skevington, S.M. A standardized scale to measure beliefs about controlling pain (BPCQ): A preliminary study. Psychol. Health 1990, 4, 221-232. [CrossRef]

12. Basińska, M.; Andruszkiewicz, A. Location of pain control and coping strategies with chronic pain by patients treated for lung cancer and colorectal cancer. Psychoonkologia 2014, 2, 43-50.

13. Williams, D.A. The importance of psychological assessment in chronic pain. Curr. Opin. Urol. 2013, 23, 554-559. [CrossRef] [PubMed]

14. Jensen, M.P.; Turner, J.A.; Romano, J.M. Changes after multidisciplinary pain treatment in patient pain beliefs and coping are associated with concurrent changes in patient functioning. Pain 2007, 131,38-47. [CrossRef]

15. Crisson, J.E.; Keefe, F.J. The relationship of locus of control to pain coping strategies and psychological distress in chronic pain patients. Pain 1988, 35, 147-154. [CrossRef]

16. Brown, C.A. The beliefs of people with chronic pain in relation to 'important' treatment components. Eur. J. Pain 2004, 8, 325-333. [CrossRef]

17. Juczyński, Z. Narzedzia Pomiaru w Promocji i Psychologii Zdrowia [Measurement Tools in Health Promotion and Psychology]; Pracownia Testów Psychologicznych PTP: Warszawa, Poland, 2012; pp. 149-155.

18. Field, A. Discovering Statistics Using IBM SPSS Statistics; Sage Publications: London, UK, 2017.

19. Stanton, A. Positive consequences of the experience of cancer: Perceptions of growth and meaning. In Psycho-Oncology; Holland, J., Breitbart, W., Eds.; Oxford University Press: New York, NY, USA, 2010; pp. 547-550.

20. Sak, J.J.; Sagan, D.M.; Pawlikowski, J.; Wiechetek, M.; Jarosz, M. Impact of beliefs about pain control on perceptions of illness in surgical patients. Ann. Agric. Environ. Med. 2016, 23, 144-147. [CrossRef]

21. Thompson, S.C. The role of personal control in adaptive functioning. In Psycho-Oncology; Snyder, C.R., Lopez, S.J., Eds.; Oxford University Press: New York, NY, USA, 2002; pp. 277-287. 
22. Berglund, E.; Lytsy, P.; Westerling, R. The influence of locus of control on self-rated health in context of chronic disease: A structural equation modeling approach in a cross sectional study. BMC Public Health 2014, 14, 492. [CrossRef]

23. Beier, M.E.; Ackerman, P.L. Determinants of health knowledge: An investigation of age, gender, abilities, personality, and interests. J. Pers. Soc. Psychol. 2003, 84, 439-448. [CrossRef] [PubMed]

24. Zielazny, P.; Biedrowski, P.; Lezner, M.; Uzdrowska, B.; Błaszczyk, A.; Zarzeczna-Bara, M. Stopień akceptacji choroby, przekonania na temat kontroli bólu oraz strategie radzenia sobie $\mathrm{z}$ bólem wśród pacjentów zakwalifikowanych do zabiegu z powodu choroby zwyrodnieniowej kregosłupa [The degree of acceptance of illness, beliefs about pain control and pain management strategies among patients qualified for surgery due to osteoarthritis of the spine]. Postęp. Psychiatr. Neurol. 2013, 22, 251-258.

25. Masters, K.S.; Wallston, K.A. Canonical correlation reveals important relations between health locus of control, coping, affect and values. J. Health Psychol. 2005, 10, 719-731. [CrossRef]

26. Pietrzyk, A. Interwencje poznawczo-behawioralne dla chorych na nowotwory i ich bliskich-możliwość podnoszenia jakości ich życia [Cognitive-behavioral interventions for cancer patients and their relatives-The opportunity to improve their quality of life]. Psychoonkologia 2008, 12, 58-65.

27. Wiśniewska, A.; Szewczyk, M.T.; Cwajda-Białasik, J.; Cierzniakowska, K.; Jawień, A. Beliefs about pain control in patients with a chronic ischemia of lower limb. Pieleg. Chir. Angiol. 2009, 3, 113-121.

28. Misterska, E.; Jankowski, R.; Głowacki, M. Chronic pain coping styles in patients with herniated lumbar discs and coexisting spondylotic changes treated surgically: Considering clinical pain characteristics, degenerative changes, disability, mood disturbances, and beliefs about pain control. Med. Sci. Monit. 2013, 19, 1211-1220. [PubMed]

29. Ozga, D.; Bielak, D.; Wojtaszek, M.; Mach-Lichota, E.; Niemczyk, E. Is it possible to control pain? The analysis of factors influencing the level of control over patient's pain experience-Preliminary report. Ból 2016, 17, 9-15. [CrossRef]

30. Dziki, Ł.; Glińska, Ł.; Borowiak, E.; Krzemińska, M.; Dziki, A. The factors that determine the pain control in patients after cardiac surgery. Pieleg. Chir. Angiol. 2017, 11, 26-31.

31. Mackey, L.M.; Blake, C.; Casey, M.B.; Power, C.K.; Victory, R.; Hearty, C.; Fullen, B.M. The impact of health literacy on health outcomes in individuals with chronic pain: A cross-sectional study. Physiotherapy 2019, 105, 346-353. [CrossRef] [PubMed]

32. Vanhaudenhuyse, A.; Gillet, A.; Malaise, N.; Salamun, I.; Grosdent, S.; Maquet, D.; Nyssen, A.-S.; Faymonville, M.E. Psychological interventions influence patients' attitudes and beliefs about their chronic pain. J. Tradit. Complement. Med. 2018, 8, 296-302. [CrossRef] 